
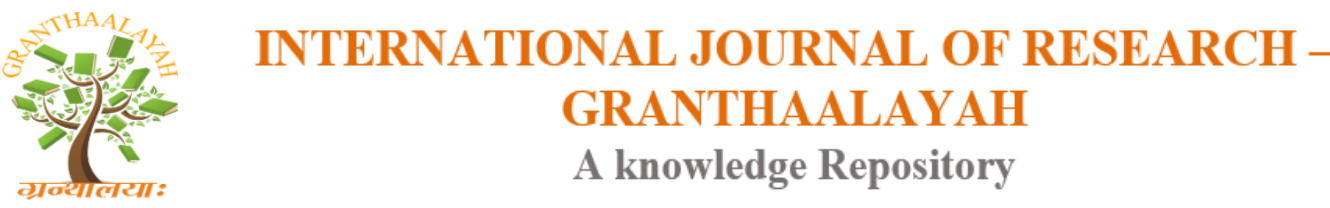

Science

\title{
MSG: AN OVERVIEW ON THE ILL EFFECTS OF THE INGREDIENT IN HUMAN FOOD CHAIN
}

\author{
Subha Ganguly *1 \\ ${ }^{* 1}$ Associate Professor, Department of Veterinary Microbiology, ARAWALI VETERINARY \\ COLLEGE (Affiliated with Rajasthan University of Veterinary and Animal Sciences, Bikaner), \\ N.H. - 52 Jaipur Road, V.P.O. Bajor, Sikar - 332001, Rajasthan, India \\ DOI: https://doi.org/10.29121/granthaalayah.v5.i1.2017.1692
}

\begin{abstract}
Monosodium glutamate, also known as MSG and sodium glutamate is used as a flavor enhancer especially in Chinese restaurant foods and snacks. It was first prepared in 1908 by Japanese biochemist Kikunae Ikeda, who was trying to isolate and duplicate the savory taste of edible seaweed called kombu, which is used as a base for many Japanese soups. ${ }^{[1]}$

Keywords: Chinese Food; Flavor Enhancer; Ill Effects; MSG.

Cite This Article: Subha Ganguly. (2017). "MSG: AN OVERVIEW ON THE ILL EFFECTS OF THE INGREDIENT IN HUMAN FOOD CHAIN." International Journal of Research - Granthaalayah, 5(1), 59-60. https://doi.org/10.29121/granthaalayah.v5.i1.2017.1692.
\end{abstract}

\section{Introduction}

MSG is used for imparting a meaty and savory odor to the food which in turn promotes an umami taste in prepared stews and meat soups. It blends and rounds the perception of other tastes. Chemically, it is the sodium salt of glutamic acid, which is one of the most important and abundantly occurring non-essential amino acids. Naturally, MSG is predominantly available in tomatoes and cheese and other foods.

\section{Methods for Manufacture}

There exist three common methods for production of MSG: (a) by hydrolysis of vegetable proteins with hydrochloric acid to disrupt peptide bonds (1909-1962), (b) by direct chemical synthesis with acrylonitrile (1962-1973) (c) the currently used bacterial fermentation method. 


\section{Clinical Signs and Symptoms}

Few population around the globe report for the MSG sensitivity among them, but concrete scientific studies have not shown any direct link between MSG and adverse reactions in humans. MSG is usually associated with "Chinese Restaurant Syndrome" because the first report was made available from the consumption of a Chinese meal and its wide use in Asian cuisines.

The clinical symptoms include nausea, sweating, burning sensations along the back of the neck, and chest block. Some other types of studies have proved that MSG causes allergic syndromes following its meal in cuisines like gravy preparations of shrimp, peanuts, spices and herbs. ${ }^{[2]}$

\section{Intake and Metabolism}

The metabolism of MSG in children and adults do not vary. Even, human breast milk contains 10 times more glutamate than cow's milk. Regular intake of MSG can lead to cause adrenal gland malfunction, seizures and diabetes mellitus along with the symptoms of high blood pressure, excessive weight gain, stroke and other health problems. Consumption of food rich in MSG also causes inflammation of the mucous membrane of GI tract. ${ }^{[3]}$

\section{Prevention}

It is always advisable to consult a clinician or nutritionist or dietician in case of sensitivity to MSG and the particular kind of food should be avoided. ${ }^{[4]}$

\section{Conclusion}

In our food supply chain MSG is one of the most extensively researched food ingredients. Many researchers and scientific evaluations have also proved that MSG is a safe and useful taste enhancer in food if consumed in limited or optimum level.

\section{References}

[1] Ikeda K (1908). A production method of seasoning mainly consists of salt of L-glutamic acid. Japanese Patent 14804.

[2] Walker, R and Lupien, J.R. (2000). School of Biological Sciences, University of Surrey, UK, and Food and Nutrition Division, FAO of the United Nations, Italy. The safety evaluation of monosodium glutamate. Journal of Nutrition, 130 (4S Suppl): 1049S-52S.

[3] Yamaguchi, Shizuko (1984). Central Research Laboratories, Ajinomoto Co., Japan; Takahashi, Chikahito, Central Research Laboratories, Ajinomoto Co., Japan. Interactions of monosodium glutamate and sodium chloride on saltiness and palatability of a clear soup. Journal of Food Science. 49 (1): 82-85. doi:10.1111/j.1365-2621.1984.tb13675.x

[4] Group, Edward (2011 - 14). The Harmful effects of Monosodium Glutamate (MSG). Global Healing Center. http://www.globalhealingcenter.com/natural-health/harmful-effects-ofmonosodium-glutamate-msg/

*Corresponding author.

E-mail address: ganguly38@gmail.com 